University of Nebraska - Lincoln

DigitalCommons@University of Nebraska - Lincoln

\title{
Mineralogy of Mine Waste at the Vermont Asbestos Group Mine, Belvidere Mountain, Vermont
}

Denise M. Levitan

U.S. Geological Survey, 954 National Center, Reston, Virginia 20192, U.S.A., dlevitan@usgs.gov

Jane M. Hammarstrom

U.S. Geological Survey, 954 National Center, Reston, Virginia 20192, U.S.A.

Mickey E. Gunter

Department of Geological Sciences, University of Idaho, Moscow, Idaho 83844, U.S.A.

Robert R. Seal II

U.S. Geological Survey, 954 National Center, Reston, Virginia 20192, U.S.A.

I-Ming Chou

U.S. Geological Survey, imchou@usgs.gov

See next page for additional authors

Follow this and additional works at: https://digitalcommons.unl.edu/usgsstaffpub

Part of the Earth Sciences Commons

Levitan, Denise M.; Hammarstrom, Jane M.; Gunter, Mickey E.; Seal II, Robert R.; Chou, I-Ming; and Piatak, Nadine M., "Mineralogy of Mine Waste at the Vermont Asbestos Group Mine, Belvidere Mountain, Vermont" (2009). USGS Staff -- Published Research. 333.

https://digitalcommons.unl.edu/usgsstaffpub/333

This Article is brought to you for free and open access by the US Geological Survey at DigitalCommons@University of Nebraska - Lincoln. It has been accepted for inclusion in USGS Staff -- Published Research by an authorized administrator of DigitalCommons@University of Nebraska - Lincoln. 


\section{Authors}

Denise M. Levitan, Jane M. Hammarstrom, Mickey E. Gunter, Robert R. Seal II, I-Ming Chou, and Nadine M. Piatak 


\title{
LETTER
}

\section{Mineralogy of mine waste at the Vermont Asbestos Group mine, Belvidere Mountain, Vermont}

\author{
Denise M. Levitan, ${ }^{1, *}$ JAne M. HAmmarstrom, ${ }^{1}$ Mickey E. Gunter, ${ }^{2}$ Robert R. Seal II, ${ }^{1}$ \\ I-Ming Chou, ${ }^{1}$ AND NAdine M. Piatak ${ }^{1}$
}

\author{
${ }^{1}$ U.S. Geological Survey, 954 National Center, Reston, Virginia 20192, U.S.A. \\ ${ }^{2}$ Department of Geological Sciences, University of Idaho, Moscow, Idaho 83844, U.S.A.
}

\begin{abstract}
Samples from the surfaces of waste piles at the Vermont Asbestos Group mine in northern Vermont were studied to determine their mineralogy, particularly the presence and morphology of amphiboles. Analyses included powder X-ray diffraction (XRD), optical microscopy, scanning electron microscopy (SEM), electron probe microanalysis (EPMA), and Raman spectroscopy. Minerals identified by XRD were serpentine-group minerals, magnetite, chlorite, quartz, olivine, pyroxene, and brucite; locally, mica and carbonates were also present. Raman spectroscopy distinguished antigorite and chrysotile, which could not be differentiated using XRD. Long-count, short-range XRD scans of the (110) amphibole peak showed trace amounts of amphibole in most samples. Examination of amphiboles in tailings by optical microscopy, SEM, and EPMA revealed non-fibrous amphiboles compositionally classified as edenite, magnesiohornblende, magnesiokatophorite, and pargasite. No fibrous amphibole was found in the tailings, although fibrous tremolite was identified in a sample of host rock. Knowledge of the mineralogy at the site may lead to better understanding of potential implications for human health and aid in designing a remediation plan.
\end{abstract}

Keywords: Asbestos, chrysotile, amphibole, mine waste, Raman spectroscopy

\section{INTRODUCTION}

The mineralogy of asbestos is an essential, yet controversial, aspect of the assessment of human-health risks associated with asbestos, especially for asbestos mine sites. Asbestos has been linked to several primarily pulmonary health problems in humans including asbestosis, lung cancer, and mesothelioma (Skinner et al. 1988; ATSDR 2001; Roggli and Coin 2004). Asbestos is an industrial term used to describe several silicate minerals that form long, thin, durable mineral fibers that have high tensile strength, flexibility, and resistance to heat (Skinner et al. 1988; Virta 2005; Van Gosen 2007). Commercially produced asbestos includes the serpentine mineral chrysotile and the amphibole minerals crocidolite (riebeckite), amosite (cummingtonite-grunerite), tremolite, actinolite, and anthophyllite, when the latter three are asbestiform. Greater than $95 \%$ of global asbestos production has been chrysotile (Virta 2005).

Controversy surrounds the relationship of specific asbestos minerals to specific pulmonary diseases. Asbestosis has been tied to all asbestos mineral species, and the U.S. Department of Health and Human Services, U.S. Environmental Protection Agency, and International Agency for Research on Cancer consider asbestos a carcinogen (ATSDR 2001). The link between mesothelioma and amphibole asbestos is indisputable, but a link with chrysotile is debated (McDonald et al. 1997; Fattman et al. 2004; Sporn and Roggli 2004; Gunter et al. 2007). One complicating factor in the chrysotile debate is that many chrysotile deposits may have asbestiform amphiboles as minor constituents of the ores (Williams-Jones et al. 2001; Van Gosen 2007). Therefore, it is difficult to discern unequivocally the effects of chrysotile from

*E-mail: dlevitan@usgs.gov those of asbestiform amphibole. Additional controversy surrounds the relative toxicity of long vs. short fibers. Numerous studies demonstrate that short fibers are cleared more effectively from the lungs than longer fibers; however, other studies suggest that shorter fibers can travel deeper into respiratory systems, making them more problematic (ATSDR 2003; Fattman et al. 2004; Plumlee et al. 2006). Thus, knowledge of the mineralogical character of asbestos minerals at specific sites is important.

The Vermont Asbestos Group (VAG) mine on Belvidere Mountain in northern Vermont was the second largest asbestos mine in the United States. Chrysotile was mined from serpentinized ultramafic rocks that are believed to be portions of ophiolites emplaced during the Taconic orogeny (Van Baalen et al. 1999). These rocks are part of a belt of serpentinites that extends northeastward into Quebec and also contains the well-known asbestos deposits at Thetford Mines (Chidester et al. 1978). The mine operated from around 1900 until 1993 (Van Baalen et al. 1999). During its peak, the mine was the source of as much as 96 to $98 \%$ of the chrysotile mined in the United States (Burmeister and Matthews 1962). Chrysotile asbestos was mined from three main areas: the Eden, the Lowell, and the C-area quarries (Fig. 1). Tailings from the mills at the site formed three areas of waste piles currently estimated to contain over $26 \mathrm{Mt}$ of material. Due to the location of milling operations throughout the site's history, it is presumed that the waste in the Eden quarry and nearby tailings pile is predominantly from the Eden quarry, whereas waste in the Lowell and $\mathrm{C}$ areas is from throughout the site.

In 2004, the Vermont Agency of Natural Resources began studying the VAG site following a complaint about the erosion of waste material into nearby wetlands. The site has become a growing concern, particularly from the perspective of human- 




FIGURE 1. Site map showing tailings and waste piles, surface water features, and topography. Topographic contours are spaced at $30.5 \mathrm{~m}(100$ $\mathrm{ft})$. Sample collection sites are shown. The site is contained within two Lake Champlain watersheds. Hutchins Brook flows into Dark Branch, which is in the Lamoille River watershed, and Burgess Branch is in the Mississquoi River watershed.

health effects, although a recent report found no significant increase in asbestos-related diseases among people living near the mine relative to residents of the rest of Vermont (Vermont Department of Health 2008, 2009).

This study, part of a larger, ongoing U.S. Geological Survey site characterization project, was conducted to assess the mineralogical character of the waste material at the VAG mine site in the context of known and debated issues related to both chrysotile and amphibole asbestos. Specific attention was focused on the distribution of amphiboles and their morphology.

\section{SAMPLES AND EXPERIMENTAL METHODS}

Sixteen composite samples of the surfaces of the tailings and waste piles at the site were collected in July 2007 (Fig. 1). Each composite was made up of at least 30 increments. All samples were dry-sieved through size 10 mesh $(2 \mathrm{~mm})$. Four samples of the processed product from the mill were collected. One came from material that had fallen from the mill's conveyor belt (07BMPO-1), one from a storage shed (07BMPO-2), and two from bags of packaged product stored in the mill (EdenOreA and EdenOreB). Grab samples of different rock types from throughout the site, including waste piles and quarries, were also collected.

Powder XRD was used to determine bulk sample mineralogy (phases comprising more than a few percent) and to detect the presence of lesser amounts of amphiboles. Back-loaded powder mounts were run on a PANalytical X'Pert Pro diffractometer with an $\mathrm{X}^{\prime}$ Celerator detector using $\mathrm{Cu} K \alpha$ radiation over a range of 3 to $70^{\circ} 2 \theta$ at $0.07^{\circ} 2 \theta / \mathrm{s}$. Samples were rerun from 9.5 to $11.5^{\circ} 2 \theta$ at $0.0001^{\circ} 2 \theta / \mathrm{s}$ to detect the amphibole (110) peak at $\sim 10.5^{\circ} 2 \theta$ (Gunter et al. 2007). Minerals were identified using PANalytical X'Pert HighScore Plus v.2.2a with patterns from the ICDD PDF-2.

More detailed analyses were done on splits of seven tailings samples and nine rock samples that were determined to be representative based on macroscopic visual characteristics and that were collected from throughout the site. These samples were examined using optical microscopy and by SEM using a JEOL JSM-840 instrument with energy dispersive X-ray spectrometer (EDS) operated at $15 \mathrm{kV}$ and 1 to $2 \mathrm{nA}$. Samples were analyzed using a JEOL JSX8900 electron microprobe with an accelerating voltage of $15 \mathrm{kV}$ and a focused beam current of
2 nA. Elements analyzed in all samples were $\mathrm{Na}, \mathrm{Ni}, \mathrm{Mg}, \mathrm{Cr}, \mathrm{Ca}, \mathrm{Al}, \mathrm{Ti}, \mathrm{Si}, \mathrm{Fe}$, and $\mathrm{K}$. Manganese and $\mathrm{F}$ were analyzed in some samples. Sulfide grains were analyzed for $\mathrm{Fe}, \mathrm{Ni}, \mathrm{Zn}, \mathrm{Cu}, \mathrm{As}$, and $\mathrm{S}$ at $20 \mathrm{kV}$. Natural and synthetic minerals were used as standards.

A JY/Horiba LabRam HR Raman system was used, with $532.06 \mathrm{~nm}$ (frequency doubled Nd:YAG) laser excitation, a 40× Olympus objective with 0.25 numerical aperture, and $\sim 20 \mathrm{~mW}$ laser power at sample surface, with various analysis times and accumulations per spectrum. Spectra were acquired with a 600 groove $/ \mathrm{mm}$ grating with a spectral resolution of $2 \mathrm{~cm}^{-1}$. Spectra were taken from rocks, mineral grains picked from bulk tailings samples, and thin sections. For comparison, spectra were taken from reference minerals from the National Museum of Natural History, and additional patterns from Rinaudo et al. $(2003,2004)$ and the RRUFF database (Downs 2006) were used to identify phases.

\section{RESULTS AND DISCUSSION}

Various silicate, carbonate, oxide, hydroxide, and sulfide minerals were identified in the composite tailings and waste samples at the site using the combination of techniques discussed above. Silicate minerals include antigorite, chrysotile, chlorite, amphibole, pyroxene, olivine, quartz, and titanite. Carbonate minerals comprise magnesite and hydrotalcite. Oxides and hydroxides include magnetite, chromite, and brucite. The lone sulfide found in this study is heazlewoodite $\left(\mathrm{Ni}_{3} \mathrm{~S}_{2}\right)$ based on a $\mathrm{Ni}$ :S ratio of 3:2 from EPMA. These results are similar to those reported by Van Baalen et al. (1999), though that study also includes minerals found in the country rock but not detected in the tailings. The tailings mineralogy is also consistent with that of rock samples collected from the quarries.

Raman spectroscopy was effective in distinguishing among the serpentine-group minerals chrysotile, antigorite, and lizardite, which have similar XRD patterns (Fig. 2). Figure 3 shows the Raman spectra for antigorite and chrysotile from sample 07EM-2. Peaks that were found to be particularly diagnostic were the antigorite bands at 1045,686 , and $377 \mathrm{~cm}^{-1}$ and the chrysotile bands at 1104,693 , and $388 \mathrm{~cm}^{-1}$ (Kloprogge et al. 1999; Rinaudo et al. 2003). Electron microprobe analysis of serpentine-group minerals $(\mathrm{n}=38)$ identified major constituents as $\mathrm{Mg}(31-43 \mathrm{wt} \% \mathrm{MgO}), \mathrm{Si}\left(32-46 \mathrm{wt} \% \mathrm{SiO}_{2}\right), \mathrm{Fe}(0.5-7 \mathrm{wt} \%$

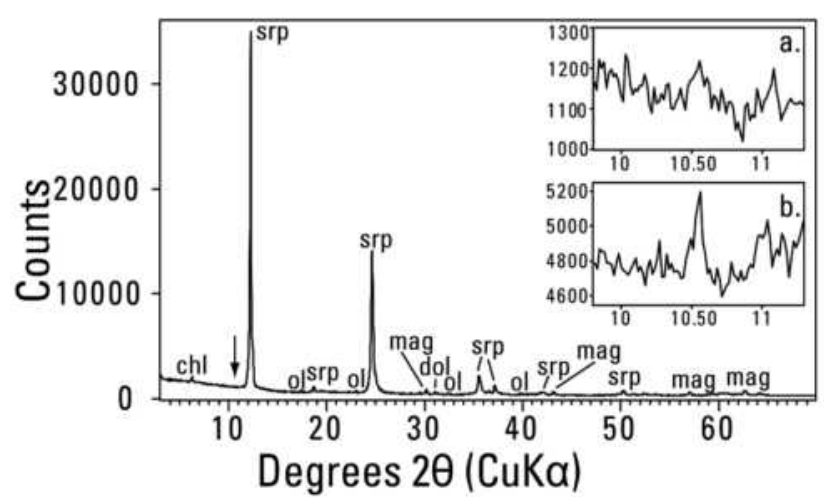

FIGURE 2. XRD scan of sample 07CT-1. Visible peaks are labeled by mineral and include chlorite (chl), dolomite (dol), magnetite (mag), olivine (ol), and serpentine (srp). The intensities of the peaks for the serpentine minerals are consistently much higher than those of the other minerals, indicating a high concentration of serpentine. Arrow indicates the location of the amphibole (110) peak. (Inset a) The area around the amphibole (110) peak at $10.5^{\circ} 2 \theta(8.42 \AA)$ expanded from this scan. The peak is not distinct from background. (Inset b) The area around the amphibole (110) peak at $10.5^{\circ} 2 \theta(8.42 \AA)$ scanned at $0.0001^{\circ} 2 \theta / \mathrm{s}$. In this second scan, the amphibole peak is clearly resolved. 


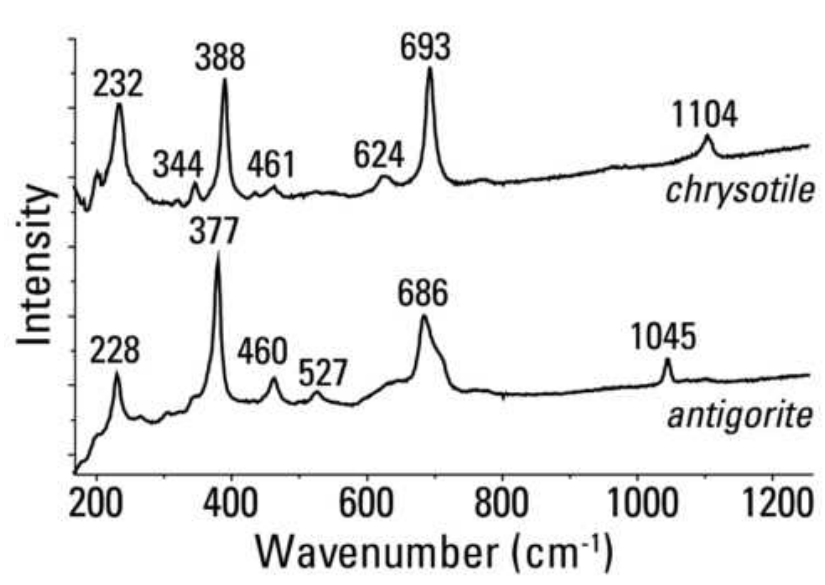

FIGURE 3. Raman spectra of two mineral grains from sample 07EM-2. Peaks are labeled by wavenumbers. These spectra were used to establish the presence of two minerals with similar composition and XRD peaks. Data were compared with published patterns (Rinaudo et al. 2003), RRUFF database patterns (Downs 2006), and those of reference samples.

$\left.\mathrm{FeO}_{\text {Total }}\right)$, and $\mathrm{Al}\left(0-17 \mathrm{wt} \% \mathrm{Al}_{2} \mathrm{O}_{3}\right)$. Trace amounts of $\mathrm{Ni}$ and $\mathrm{Cr}\left(0.05-0.55 \mathrm{wt} \% \mathrm{NiO}, 0-3 \mathrm{wt} \% \mathrm{Cr}_{2} \mathrm{O}_{3}\right)$ were also measured. Results from polarized light microscopy analysis for asbestos type and quantity by EPA test method 600/R-93/116 (Perkins and Harvey 1993) ranged from 18 to $91 \%$ chrysotile by point count. Fibers in the tailings generally ranged in length from $<5$ $\mu \mathrm{m}$ to $5 \mathrm{~mm}$, although longer fibers were present and may have been removed from the samples during sieving (Fig. 4a). In the processed product, fiber size is variable; the mill was able to produce 35 to 40 grades made up of different blends of fiber lengths (Burmeister and Matthews 1962). Samples 07BMPO-1 and EdenOreA contain fiber lengths of the same range as the tailings samples. Sample 07BMPO-2 contains only short fibers, whereas EdenOreB contains fibers of up to a centimeter or more. Occurrences of all three serpentine minerals have been reported at the site, with antigorite being the most and lizardite the least abundant (Van Baalen et al. 1999).

The long-count, short-range XRD scans for amphiboles (Fig. $2 \mathrm{~b}$ ) indicated the presence of amphiboles in 12 of the 16 tailings samples. The four samples that did not have detectable amphibole were from the tailings pile at the lower area of the Eden quarry (samples 07ET-1, -2, -3, and -4). Three of the four processed concentrate samples (07BMPO-1, EdenOreA, and EdenOreB) were also lacking in amphibole. However, an amphibole grain was found in a thin section of one of the Eden tailings samples that did not have XRD-detectable amphibole. No detection limit was determined for these samples, though a study using identical methods but a different diffractometer model for tremolite in processed chrysotile found a detection limit of $500 \mathrm{ppm}$ for a long count XRD scan (Gunter et al. 2007). EPMA demonstrated that amphiboles $(n=4)$ were calcic to sodic-calcic and aluminumbearing, with $\mathrm{Mg} /\left(\mathrm{Mg}+\mathrm{Fe}^{2+}\right)$ ratios of approximately 0.7 , and classified as edenite, magnesiohornblende, magnesiokatophorite, and pargasite on the basis of their mineral chemistry (Leake et al. 1997). Similar compositions were reported by Chidester et al. (1978) for amphibole from the coarse amphibolites of the host Belvidere Mountain Formation. Figure 4 shows examples
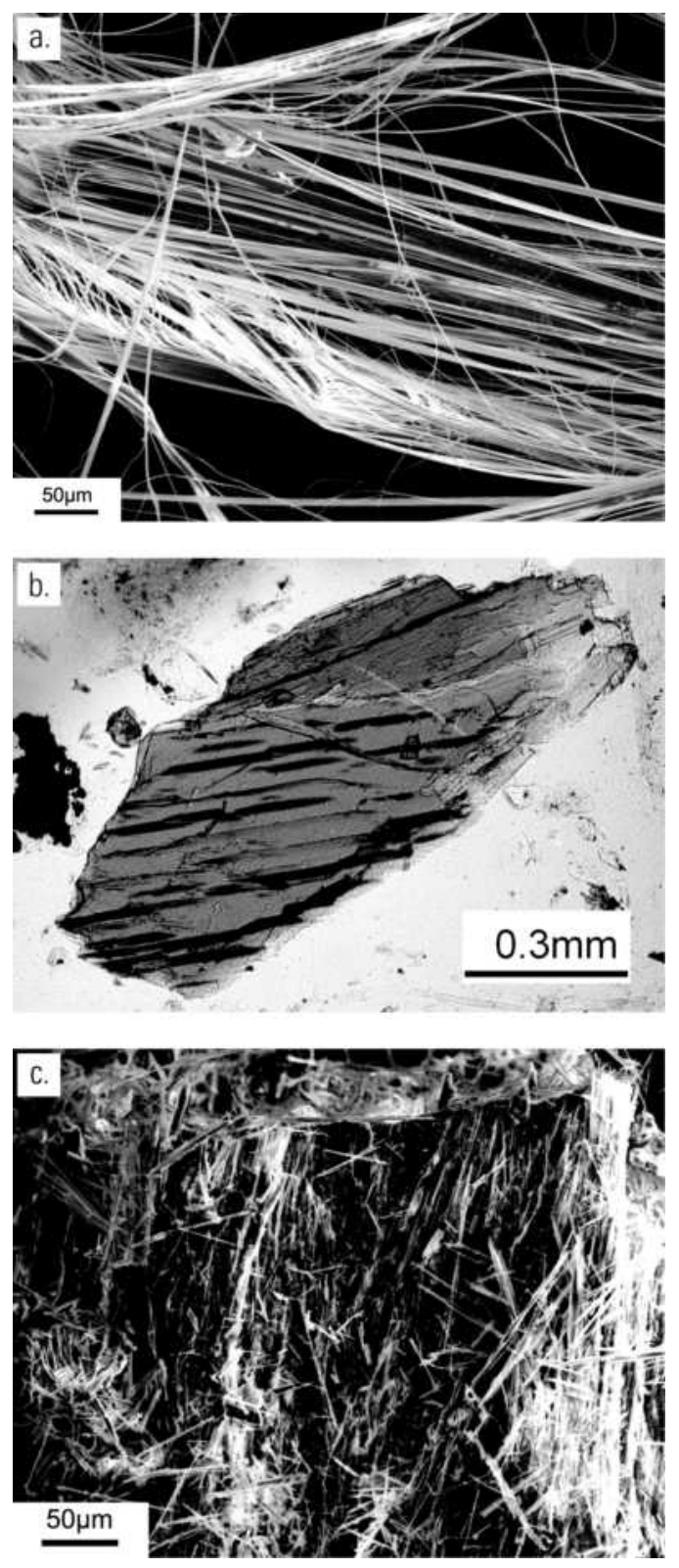

FIGURE 4. Amphibole and asbestos minerals. (a) SEM secondary electron image of chrysotile asbestos fibers from rock sample 07LM-RA. This sample contains veins of cross-fiber chrysotile and was collected from the Lowell quarry. (b) Amphibole grain from thin section of sample $07 \mathrm{EM}-1$. This grain is not asbestiform; the aspect ratio is approximately 2.3. (c) SEM secondary electron image of fibrous tremolite in rock sample 07CM-RA, which was collected from loose rocks in the C-area quarry. The sample also contains abundant antigorite.

of chrysotile asbestos, a non-asbestiform amphibole, and fibrous tremolite from the site. Amphiboles have been reported in the host rock, including fibrous tremolite in contact rock between blackwall and steatite (Chidester et al. 1978) in addition to nonfibrous occurrences. To date, none of the amphiboles found in the tailings samples have been fibrous. However, a loose rock sample collected from the C-area quarry (07CM-RA) contained tremolite identified by XRD, Raman spectroscopy, and EPMA. Examination of this sample by SEM revealed that the tremolite 
was fibrous (Fig. 4c). XRD and Raman analysis found that the only other mineral present in this sample in amounts detectable by XRD was antigorite. Chidester et al. (1978) reported finding a small amount of loose tremolite-actinolite asbestos intergrown with fibrous calcite at the Lowell quarry. A study of air filters collected during operation of the mine, mill, and bagging room found no amphiboles among fibers collected (Wylie and Bailey 1992).

The presence of amphibole at the site is significant because amphibole asbestos may be more hazardous to human health than chrysotile asbestos, particularly with respect to lung cancer and mesothelioma (McDonald et al. 1997; Van Baalen et al. 1999; Fattman et al. 2004; Sporn and Roggli 2004; Gunter et al. 2007). This study has only identified non-asbestiform amphibole in the composite samples from waste piles at the site. However, fibrous amphibole has been identified at the site in a sample of the country rock. To date, chrysotile is the only asbestos mineral detected in the tailings at the site and is a major constituent of the surface material of the piles. Although fibrous amphibole is present in the host rock at the VAG mine and amphiboles were detected in the finer-grained waste from the site, this study found no amphibole asbestos in the tailings.

The fiber size of asbestos, including chrysotile, may also have an impact on the malignancy of asbestos (ATSDR 2003; Fattman et al. 2004; Plumlee et al. 2006). The range of chrysotile fiber lengths in the waste piles at the site $(<5 \mu \mathrm{m}$ to $>5 \mathrm{~mm})$ spans the entire range of lengths that have been investigated in studies of laboratory animals and humans. In general, the average length of fiber retained increases with time of exposure; a fiber length of $10 \mu \mathrm{m}$ appears to mark a transition between shorter $(<10 \mu \mathrm{m})$ and longer $(>10 \mu \mathrm{m})$ residence times in the body (Fattman et al. 2004). Much of the long-term significance of fiber length in the waste piles at the site will depend upon remediation plans. The current surface of most of the waste piles is cemented by secondary magnesium carbonate minerals such as hydromagnesite, which partially mitigate wind-blown transport of mineral dusts from the site (Wilson et al. 2006), though erosion and stability remain concerns.

\section{ACKNOWLEDGMENTS}

Thanks to John Schmeltzer and Linda Elliott of the Vermont Agency of Natural Resources, and Larry Becker, Marjorie Gale, and Jon Kim of the Vermont Geological Survey for useful discussions and fieldwork assistance; to Joe East of the USGS for advice; and Matt Kierstead of PAL Inc. and Jason Clere of URS Corp. for helpful discussions. This manuscript benefitted from reviews by Allan Kolker, John Schmeltzer, Mark Van Baalen, and an anonymous reviewer. The use of trade names is for descriptive purposes only and does not imply endorsement by the U.S. Government.

\section{REFERENCES CITED}

ATSDR (2001) Toxicological profile for asbestos. Agency for Toxic Substances and Disease Registry, Atlanta.

(2003) Report on the expert panel on health effects of asbestos and synthetic vitreous fibers: The influence of fiber length. Agency for Toxic Substances and Disease Registry, Atlanta.

Burmeister, H.L. and Matthews, I.E. (1962) Mining and milling methods and costs, Vermont Asbestos Mines, the Ruberoid Co., Hyde Park, Vermont. U.S. Bureau of Mines Information Circular 8068.

Chidester, A.H., Albee, A.L., and Cady, W.M. (1978) Petrology, structure, and genesis of the asbestos-bearing ultramafic rocks of the Belvidere Mountain area in Vermont. U.S. Geological Survey Professional Paper 1016.

Downs, R.T. (2006) The RRUFF Project: an integrated study of the chemistry, crystallography, Raman and infrared spectroscopy of minerals. Program and Abstracts of the 19th General Meeting of the International Mineralogical As- sociation in Kobe, Japan, O03-13.

Fattman, C.L., Chu, C.T., and Oury, T.D. (2004) Experimental models of asbestosrelated diseases. In V.L. Roggli, T.D. Oury, and T.A. Sporn, Eds., Pathology of Asbestos-Associated Diseases, 2nd edition, p. 256-308. Springer, New York.

Gunter, M.E., Sanchez, M.S., and Williams, T.J. (2007) Characterization of chrysotile samples for the presence of amphiboles: the Carey Canadian Deposit, southeastern Quebec, Canada. Canadian Mineralogist, 45, 263-280.

Kloprogge, J.T., Frost, R.L., and Rintoul, L. (1999) Single crystal Raman microscopic study of the asbestos mineral chrysotile. Physical Chemistry Chemical Physics, 1, 2559-2564.

Leake, B.E. and 21 others (1997) Nomenclature of the amphiboles: Report of the subcommittee on amphiboles of the International Mineralogical Association, Commission on New Minerals and Mineral Names. Canadian Mineralogist, $35,219-246$.

McDonald, A.D., Case, B.W., Churg, A., Dufresne, A., Gibbs, G.W., Sebastien, P., and McDonald, J.C. (1997) Mesothelioma in Quebec chrysotile miners and millers: Epidemiology and etiology. Annals of Occupational Hygiene, $41,707-719$.

Perkins, R.L. and Harvey, B.W. (1993) Method for the determination of asbestos in bulk building materials. U.S. Environmental Protection Agency EPA/600/R/93/116

Plumlee, G.S., Morman, S.A., and Ziegler, T.L. (2006) The toxicological geochemistry of Earth materials: An overview of processes and the interdisciplinary methods used to understand them. In N. Sahai and M.A.A. Shoonen, Eds., Medical Mineralogy and Geochemistry, 64, p. 5-57. Reviews in Mineralogy and Geochemistry, Mineralogical Society of America, Chantilly, Virginia.

Rinaudo, C., Gastaldi, D., and Belluso, E. (2003) Characterization of chrysotile, antigorite and lizardite by FT-Raman spectroscopy. Canadian Mineralogist, $41,883-890$.

Rinaudo, C., Belluso, E., and Gastaldi, D. (2004) Assessment of the use of Raman spectroscopy for the determination of amphibole asbestos. Mineralogical Magazine, $68,455-465$.

Roggli, V.L. and Coin, P. (2004) Mineralogy of asbestos. In V.L. Roggli, T.D. Oury, and T.A. Sporn, Eds., Pathology of Asbestos-Associated Diseases, 2nd edition, p. 1-16. Springer, New York.

Skinner, H.C.W., Ross, M., and Frondel, C. (1988) Asbestos and Other Fibrous Materials, 222 p. Oxford University Press, U.K.

Sporn, T.A. and Roggli, V.L. (2004) Mesothelioma. In V.L. Roggli, T.D. Oury, and T.A. Sporn, Eds., Pathology of Asbestos-Associated Diseases, 2nd edition, p. 104-168. Springer, New York.

Van Baalen, M.R., Francis, C.A., and Mossman, B.T. (1999) Mineralogy, petrology, and health issues at the ultramafic complex, Belvidere Mt., Vermont, U.S.A. In S.F. Wright, Ed., New England Intercollegiate Geologic Conference Guidebook Number 91, p. 95-111. University of Vermont, Burlington.

Van Gosen, B.S. (2007) The geology of asbestos in the United States and its practical applications. Environmental and Engineering Geoscience, 13, 55-68.

Vermont Department of Health (2008) A cross-sectional study of asbestosrelated morbidity and mortality in Vermonters residing near an asbestos mine; http://www.healthvermont.gov/enviro/asbestos/documents/VAG-MineReport120908.pdf.

(2009) Case series follow-up to a cross-sectional study of asbestos-related morbidity and mortality among Vermonters residing near an asbestos mine; http://healthvermont.gov/enviro/asbestos/documents/VAG-CaseSeriesRpt0409.pdf.

Virta, R.L. (2005) Mineral commodity profiles—asbestos. U.S. Geological Survey Circular 1255-KK.

Williams-Jones, A.E., Normand, C., Clark, J.R., Vali, H., Martin, R.F., Dufresne, A., and Nayebzadeh, A. (2001) Controls of amphibole formation in chrysotile deposits: Evidence from the Jeffrey Mine, Asbestos, Quebec. In R.P. Nolan, A.M. Langer, M. Ross, F.J. Wicks, and R.F. Martin, Eds., The Health Effects of Chrysotile Asbestos, 5, p. 89-104. Canadian Mineralogist Special Publication.

Wilson, S.A., Raudsepp, M., and Dipple, G.M. (2006) Verifying and quantifying carbon fixation in minerals from serpentine-rich mine tailings using the Rietveld method with X-ray powder diffraction data. American Mineralogist, 91, 1331-1341.

Wylie, A.G. and Bailey, K.F. (1992) The mineralogy and size of airborne chrysotile and rock fragments: Ramifications of using the NIOSH 7400 method. American Industrial Hygiene Association Journal, 53, 442-447.

MANUSCRIPT RECEIVED MARCH 27, 2009

MANUSCRIPT ACCEPTED APRIL 16, 2009

MANUSCRIPT HANDLED BY BRYAN CHAKOUMAKOS 